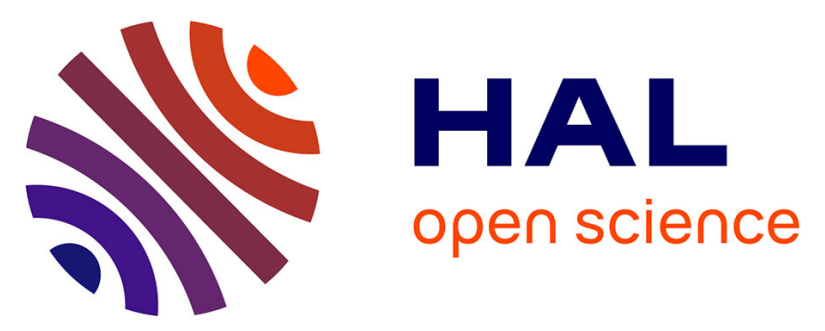

\title{
Phenology and reproductive effort of cultivated and wild forms of Pennisetum glaucum under experimental conditions in the Sahel: implications for the maintenance of polymorphism in the species
}

Jean-François Renno, Thierry Winkel

\section{To cite this version:}

Jean-François Renno, Thierry Winkel. Phenology and reproductive effort of cultivated and wild forms of Pennisetum glaucum under experimental conditions in the Sahel: implications for the maintenance of polymorphism in the species. Canadian Journal of Botany, 1996, 74 (6), pp.959-964. 10.1139/cjb74-6-959 . ird-00142188

\author{
HAL Id: ird-00142188 \\ https://hal.ird.fr/ird-00142188
}

Submitted on 17 Apr 2007

HAL is a multi-disciplinary open access archive for the deposit and dissemination of scientific research documents, whether they are published or not. The documents may come from teaching and research institutions in France or abroad, or from public or private research centers.
L'archive ouverte pluridisciplinaire HAL, est destinée au dépôt et à la diffusion de documents scientifiques de niveau recherche, publiés ou non, émanant des établissements d'enseignement et de recherche français ou étrangers, des laboratoires publics ou privés. 


\title{
Phenology and reproductive effort of cultivated and wild forms of Pennisetum glaucum under experimental conditions in the Sahel: implications for the maintenance of polymorphism in the species
}

\author{
J.-F. Renno and T. Winkel
}

\begin{abstract}
In the Sahel region of Africa, the wild and the cultivated forms of pearl millet, Pentisetum glanctum (L.) $\mathrm{R} . \mathrm{Br}$., are sympatric and interfertile and yet have remained distinct for millenia. Reproductive barriers are not sufficient to explain this situation. To eluciditte other possible mechanisms, the two forms were compared under experimental conditions in the Sahel for their phenology and reproductive effort. The length of the flowering period of each type was nuch longer than the average individual flowering period. When the last cultivated plants were linishing llowering, $65 \%$ of the wild plants were still flowering and $30 \%$ were just starting to thower. Thus, the last group was completely isolated from cultivated pearl millet gene flow (endogamic reproduction). The two forms of pearl millet also differed in the distribution of aboveground bionatss among different plant parts, except for the number of seeds per plant. Both phenological behaviour and reproductive effort contribute to the maintenance of distinct forms of wild and cultivated pearl millet.
\end{abstract}

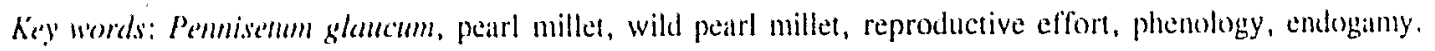

\begin{abstract}
Résumé : Dans les régions sahéliennes d'Afrique, les formes satuvage et cultivée du mil (Pénnisctum ghlanrum (L.) R.Br.) sont sympatrig̨ues et intertertiles, mais demeurent néanmoins distinces depuis des millénaires. les batrières a la reprodection ne suffisent pas à expliguer cette situation. Dans le but d'identifier d'atures mecautsmes en jeu, lat phémologie el lelfort reproductif des deax formes de mil on écé comparés en situation expérinentale au Sahtel. La

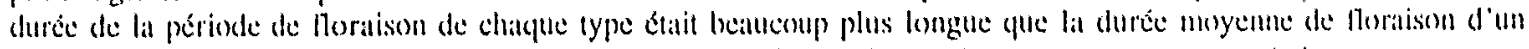

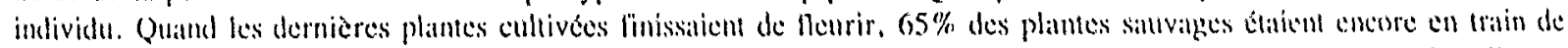

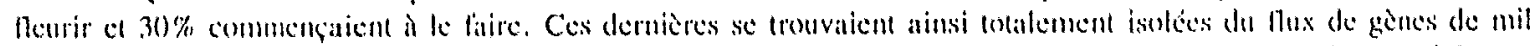

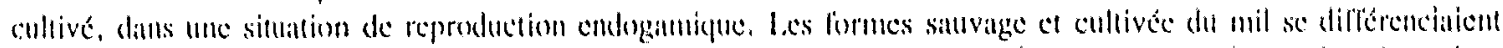
Egatencent par la répartition de keur investissenkent dians la biombisse aériennce a l'excention du nombre de graincs

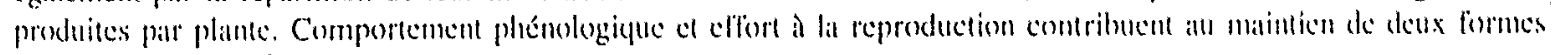
distinctes de mil.
\end{abstract}

Mets clés : Pèmisctum glaucum. mil cultivé, mil sauvage, effort reproductif, phénologic, condoganic.

\section{Introduction}

Archaeological traces of imprints of both wild and cultivated pearl millet (Penniscrum glaucum) seeds and bristles on pottery, found in southeast Mauritania and dating from around $3000 \mathrm{BP}$, are evidence of a neolithic agriculture with cultivated and wild pearl millet populations in sympatry (Amblard and Pernès 1989). The current wild form is distributed across the northern Sahel and is phylogenetically close to the ancestor of the cultivated pearl millet (Harlan 1975: Portères 1976).

Van der Zon (1992) recognized three subspecies in Pellnisctum glaucum (L.) R.Br.: P. glaucum ssp. glaucum, the cultivated pearl millet; $P$. glaucum ssp. riolacelum (Lam.) A. Rich., the wild and weedy forms: and $P$. glaucam ssp.

Received June 30, 1995.

J.-F. Renno' and T. Winkel. ORSTOM, Intltut français de recherche scientilique pour le developpement en coopération. B.P. 11416. Niamey, Niger.

1 Author to whom all correspondence should be addressed at Le: Verger, 86370 Vivomin. France. sicheriamum (Schlecht.) Stapl \& Hubb.. the intermediate form between the wild and the cultivated forms, known as shibra in Niger. These three laxa belong to the same gene pool of the allogamic and polymorphic annual species. P. glaucum (L.) R.Br. (Harlan and de Wet 1971).

Regarding the cultivated pearl millet. the farmer plays an essential selective role through agriculural practices: choice of seeds from spikes typical for a locit cultivar, batches of seeds (called pockets) sown into holes fivoring the growth of the biggest seeds, hoeing to eliminate weeds and pearl millet plants outside the pockets, thinning out to preserve the most vigourous plants, and elimination of the shibra. Nevertheless, in the field, the frequency of the remaining shibra varies between 5 and $30 \%$ in the areas where the wild and cultisated forms are in contact (Rey-Herme 1982). These wild populations are not subject to conscious selection pressure by humans. For two samples of seeds taken from wild pearl millet populations in Senegal and Niger, the proportion of descendants of the hybrid phenotype (shibra), supposedly the product of fertilization by cultivated pollen, was estimated at 31 and $19 \%$, respectively (Marchais and Tostain 1992,

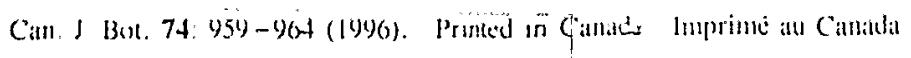


How is the polymorphism of $P$. glatuckm maintained? How is it that wild pearl millet does not disappear in contact with cultivated pearl millet under the effects of gene flow?

Many studies have addressed these questions. Studies of genelic distance indicated strong intermixing of genes between wild and cultivated pearl millet (Tostain 1993). Pernes (1983, 1985) underlines the fact that the two forms interact but can exchange alleles without a modification of phenotypes because the genetic control of domestication is supposed to depend on a few linked genes. Moreover, gene tlow can be controlled by mechanisms that act at the pre-and post-zygote stages in favour of the maintenance of differentiation between the wild and cultivated forms. Pollen competition was observed as a prezygote barrier, giving the advantage to self-pollination (Sarr et al. 1988; Robert et al. 1991), while the reduction in viability of hybrid grains was observed as a postzygote brake (Amoukou and Marchais 1993). Genomic strategies in wild pearl millet in contact with cultivated pearl millet were mentioned by Joly-Ichenhauser (1984) and Pernes (1986), who assume the existence of two linkage groups of predomestication genes that would have the effect of favouring the maintenance of phenotypes in spite of hybridization. However, if these reproductive barriers limit gene flow, they do not entirely eliminate it and are not sufficient by themselves to explain the matintenance of two distinct interfertile forms in contact for millenia. Isolated reproduction in spatce and also in time, as well as selective pressures, could platy an essential role in structuring the polymorphism ol pearl millet.

Where wild and cullivaled forms of peanl mille are in geographical contacl, what is the proportion of plants in carch form cistaping the gone llow of the ofher form by asynchronic llowering periods? What are the diflerences in reprodective effort between wild and cultivaled pearl millet? How are the differences maintained between sympatric wild and cultivated populations that have been exchanging genes for millenial?

In an attempt to address these questions, we compared, under Salhelian experimental conditions. the phenology of tillering and flowering of a wild pearl millet and a cultivated pearl millet from the same geographical region, as well as the distribution of aboveground biomatss production between regetative and reproductive organs in cach of these two forms.

\section{Materials and methods}

\section{Material}

The seeds used for the study samples were collected from hundreds of spikes for each form. in six sites hetween Belbeji $\left(14^{\circ} 43^{\prime} \mathrm{N}\right.$. $\left.8^{\prime} 05^{\prime} \mathrm{E}\right)$ and Tanoul $\left(14^{\circ} 57^{\prime} \mathrm{N}, 8^{\circ} 49^{\prime} \mathrm{E}\right)$ in Niger, where wild and cultivalted pearl millet (cv. Ankoutess) are sympatric. 'Ankoutess' is adapted to a short rainy season ( 3 monthis from June to Septemter) and thus can be considered as minimally or not at all photoFeriod sensitive (Clément 1985: Burton and Powell 1968 in Skerman and Riveros 1990). The seeds of wild plants were harvested near feart millet fields.

\section{Experimental protocol}

The experintent wass catried out at the lmstitut des Radio-Isotopes IIRI). Universily of Nianey (Niger) in 1903. The soil at this tedtion is typical of larm land in the Salhel, with 9.3\% sand in the 1)- (1) 150-c'in layer. The study took plate in the hot dry season hetween Fobruary and May. The daily mean temperature varied between 26 and $37^{\circ} \mathrm{C}$, and the daily mean incident radiation between 17 and $27 \mathrm{MJ} /\left(\mathrm{m}^{2} \cdot\right.$ day). Irrigation was regulated to sinulate the average rainfall regime during the rainy scason in the region of Tanout. It was started on February 9, one day before sowing, then stopped 74 days after emergence (DAE, date at which $50 \%$ of the pockets had emerged). There was one natural rainfall at $71 \mathrm{DAE}$ $(7.5 \mathrm{~mm})$. Weeds were controlled manually. Fertilizers were supplied at $30 \mathrm{~kg} \cdot \mathrm{ha}^{-1} \mathrm{~N}, \mathrm{P}$, and $\mathrm{K} /$ day before sowing and $15 \mathrm{~kg} \cdot \mathrm{ha}^{-1} \mathrm{~N}$ at 16 DAE.

The experimental fiedd was divided into five replications with two subplots each. The subplots measured $4 \times 10 \mathrm{~m}$, sown either with cultivated or wild seeds, and were randomized per replication. Seeds were sown in pockets $\left(1\right.$ pocket $\left./ \mathrm{m}^{2}\right)$ and the development of eight pockets in the center of each subplot was observed. The first DAE was the same for wild pearl millet and cultivated pearl millet, 3 days after sowing. At 15 DAE, the cultivated plants were thinned out to three plants per pocket, a planting density considered to be optimal under Sahelian conditions (Institut National de Recherches Agronomiques du Niger 1987). In each pocket one randomly chosen plant was observed until the end of its cycle. For the wild plants, no standard density can be representative of the lack of homogeneiry in density of natural populations. For the convenience of observations, taking into account the very important tillering of each plant, the wild plants were thinned to 1 plant $/ \mathrm{m}^{2}$. This experimental approach resulted from a compromise between the need to collect precise information on each individual plant and the need to observe the phenotypic expression of each plant form as it is found under natural conditions.

\section{Observations}

The observations of the phenolugy of howering and tillering were planned for 40 plants of eath form of pearl milles, but his number hated to be reduced to 32 cultivilted plants alter the intermediate forms (the shibra type identilied afler llowering) had been discarded. Tle linal production of abovegroned biontaks wats planned to be measured on a subsimmple of 20 plants of cach form harvested at 90 days. This number wats redeced to 17 culcivated plants (after the shibra had been removed) and 10 19 wild plants, ane having died belore the harvest. No shibra was identitied in the sample of wild pearl millet. Afer llowering. envelopes were put over the spikes of the wild plants to prevent shedding of the seceds (the cultivated plants do mot shed their seeds).

\section{Phenology' of tillering and flenering}

Every 2 or 3 days during the development of the plants, the foilowing observations were male. (i) The number of plants in the primary tillering phase: a plant was considered to be in the primary tillering phase during the whole period between the development of the first and the last primary tiller (the primary tillers are those growing out of the first stem that has cmerged). The young pearl millet plants. particularly the wild plants. are too fragile to be frequently manipulated. so the observations began at 17 DAE (2 days alter thinning) for the cultivated form and at 30 DAE (15 days after thinning) for the wild form. The observations were made until harvest. (ii) The number of plants in the nowering phase: a plant wals considered to be in the flowering phase during the whole period between the hirst and the last flower. The tlowering phase for the cultivated form begins with the llowering of the spike of the main stem (the first stem energed) and ends with a spike of a primary tiller. Since the number of printary tillers was low and secondary tillers were very rare and always sterile, the flowering phase could be followed exhaustively for eirch plant. With the wild form, the nowering phase also begits with the nowering of the spike of the first stem (the equivalent of the main stem of the cultivated plant) but ends with the flowering of the spikes of the last additional tiller 
Fig. 1. Phenology of tillering $(a)$ and flowering $(b)$ in cultivated (口) and wild ptarl millet (a).

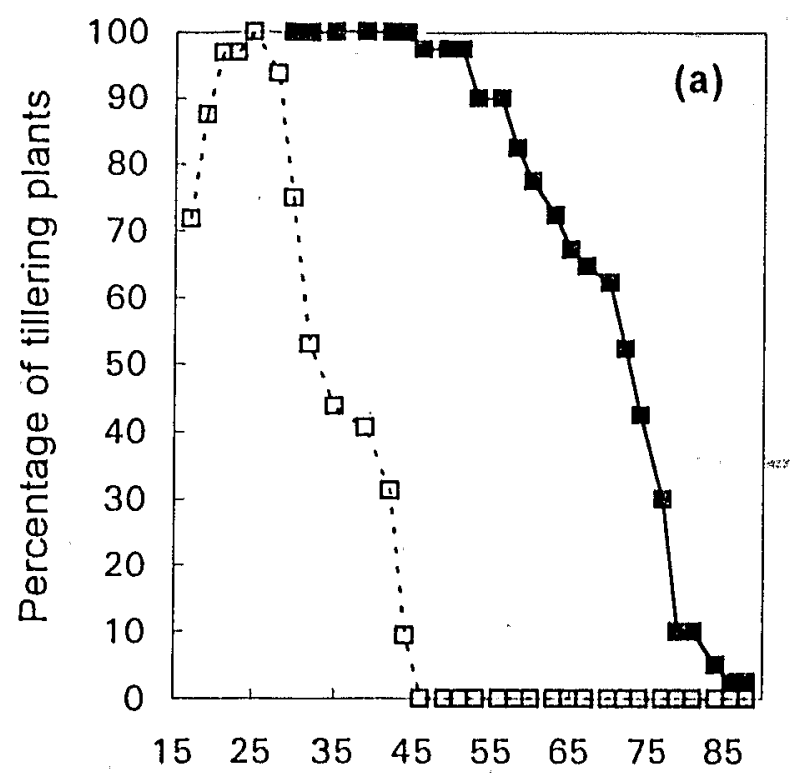

Days after emergence

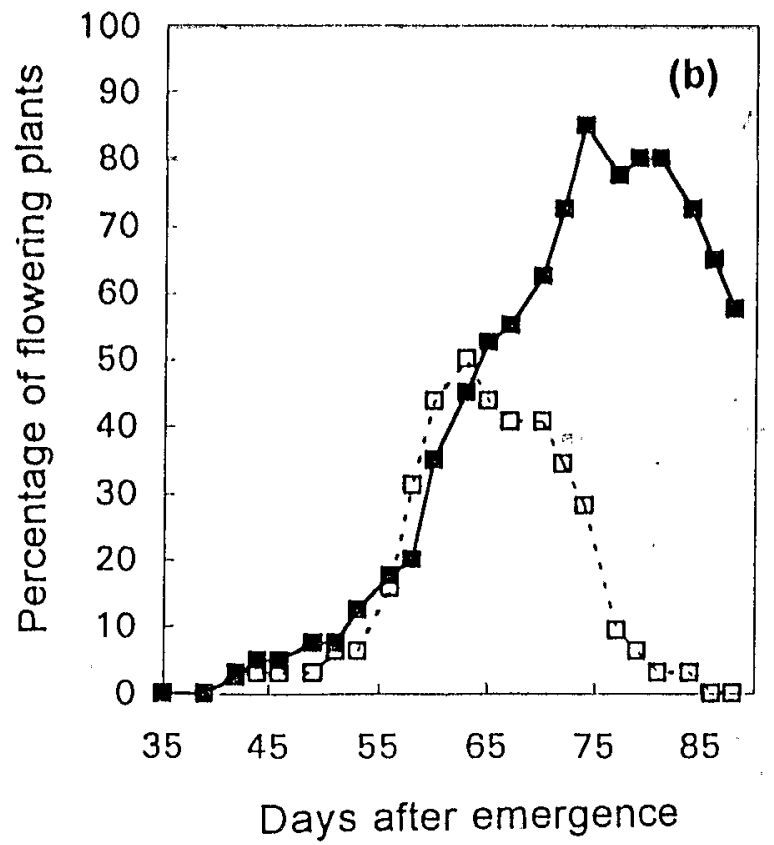

(derived from the $n$th rank of a primary tiller). For each wild plant, the flowering period of the first stem, of the first primary tiller, and of the last tiller were noted carefully. Thus, the whole of the flowering period of each plant was covered.

\section{Aboveground biomass production at harvest}

At harvest, the plants were separated out into stems, leaves, and spikes and dried at $80^{\circ} \mathrm{C}$, until a constant weight was reached $(72 \mathrm{~h})$. For each plant, the measurements of the biomass and the following counts were carried out: (i) vegetative organs: mass of stems (mSt), mass of leaves ( $m L$ ), total biomass (TAm), number of primary tillers (nbTi); (ii) reproductive organs: number of spikes (nbSp), mass of spikes before threshing ( $m S p$ ), and after threshing, mass of seeds (mSd) and number of seeds (nbSd).

The reproductive effort was estimated by $(i)$ the reproductive ratio (RR), which is the mass of the reproductive organs (spikes including seeds) divided by the total biomass and (ii) the seed ratio (SR), which is the mass of seeds divided by the total biomass.

An estimation was made of the potential number of seeds per plant $(\mathrm{pSd} / \mathrm{Pl})$, the potential number being the maximum number of seeds produced if all the ovules (one per spikelet in pearl millet) had produced seeds. A sample of spikes (40 and 63 spikes for the cultivated and wild forms, respectively) was taken at random from the total number of spikes produced by each form of pearl millet. The number of involucres on the central portion of each spike was counted for a length of 1.5 to $3 \mathrm{~cm}$ depending on the size of the spike. On each spike, the number of spikelets per involucre was counted ( 1 for wild, $1-3$ for cultivated pearl millet). After measuring the total length of the spikes, the mean potential number of seeds per spike was calculated and multiplied by the number of spikes per plant to obtain the potential number of seeds per plant (pSd/Pl).

The differences observed between cultivated and wild forms were tested by a $t$ test as a $5 \%$ probability level.

\section{Results}

Phenology of tillering

At the start of our observations at $17 \mathrm{DAE}, 72 \%$ of the cultivated plants were at the tillering phase; this proportion was $100 \%$ at 25 DAE (Fig. 1a). The tillering period of cultivated plants was complete at 44 DAE. The proportion of wild plants in the tillering phase (Fig. 1a) was 100\% at 30 DAE, at the beginning of our observations. All the plants rematined in the tillering phatse up to 44 DAF and at harvest (90 DAE) $2.5 \%$ of them were still producing new tillers. The tillering phase of the wild plants continued, therefore, well after that of the cultivaled plants.

\section{Phenology of thowering}

The average llowering period of a cullivalled plant was 7.5 days, whereas that of a wild plant was 21 days with strong individual variations for both (CV of $39 \%$ for the wild sample and $70 \%$ for the cultivated sample) (Table 1). However, the total llowering time of the samples was 45 days for cultivated pearl millet and more than 49 days for wild pearl millet, since the latter population had not finished flowering at harvest (Fig. 16).

The distribution over time of the percentage of cultivated plants in the flowering phase followed a normal curve. Flowcring began at $42 \mathrm{DAE}$, when the tillering phase was finished. The maximum level was attained at 63 DAE. with $50 \%$ of the plants flowering. At 77 DAE, about $10 \%$ of the plants were continuing to flower. There were no more llowers after 84 DAE.

The same type of distribution was observed for the wild plants. They began to flower at 42 DAE, well before the end of their tillering phasc. The maximum number of plants in the flowering phase (85\%) was at 74 DAE, when about $30 \%$ of the cultivated plants were flowering. When the last cultivated plants were finishing flowering at $84 \mathrm{DAE}, 65 \%$ of the wild plants sample were going to exchange genes only among themselves; thus reproduction was endogamic. When irrigation was stopped (7+ DAE), 30\% of the wild plants were statting to llower and more than $80 \%$ of their llowering 
Table-1. Distribution of aboveground biomass production, seed potential, reproductive ratio, seed ratio, and flowering duration of cultivated and wild pearl millet plants (means per individual).

\begin{tabular}{|c|c|c|c|c|c|c|c|c|c|c|c|c|}
\hline & $\mathrm{mSt}$ & $\mathrm{mL}$ & $\mathrm{mSp}$ & $\mathrm{mSd}$ & TAm & $\mathrm{nbSp}$ & nbSd & $\mathrm{nbTi}$ & $\mathrm{pSd} / \mathrm{Pl}$ & RR & $\mathrm{SR}$ & Flowering \\
\hline \multicolumn{13}{|c|}{ Cultivated } \\
\hline Mean & 63.4 & 43.7 & 38.2 & 22.6 & 146.9 & 1.6 & 3194 & 6.8 & 8365 & 0.25 & 0.14 & 7.5 \\
\hline$N$ & 17 & 17 & 17 & 17 & 17 & 17 & 17 & 17 & 17 & 17 & 17 & 32 \\
\hline $\mathrm{CV}$ & 46 & 46 & 64 & 71 & 42 & 71 & 68 & 19 & 71 & 52 & 60 & 70 \\
\hline SE & 7.0 & 4.9 & 5.9 & 3.9 & 14.8 & 0.3 & 525 & 0.3 & 1432 & 0.03 & 0.02 & 0.9 \\
\hline \multicolumn{13}{|c|}{ Wild } \\
\hline Mean & 252.5 & 94.0 & 79.9 & 4.9 & 426.3 & 89.9 & 4158 & 16.2 & 32312 & 0.18 & 0.01 & 20.9 \\
\hline$N$ & 19 & 19 & 19 & 19 & 19 & 19 & 19 & 19 & 19 & 19 & 19 & 40 \\
\hline $\mathrm{CV}$. & 52 & 41 & 67 & 108 & 44 & 75 & 108 & 21 & 75 & 54 & 98 & 39 \\
\hline SE & 29.9 & 8.8 & 12.3 & 1.2 & 42.6 & 15.4 & 1026 & 0.8 & 5528 & 0.02 & 0.003 & 1.3 \\
\hline
\end{tabular}

Note: Abbreviations ate as follows: $\mathrm{mSt}$, mass of stens; $\mathrm{mL}$, mass of leaves; $\mathrm{mSp}$, mass of spikes; mSd, mass of seeds; TAm, total biomass; nbSp, number of spikes; nbSd, number of seeds; nbTi, number of primary tillers; pSd/PI, potential seed number per plant; RR, reproductive ratio; SR, seed ratio; flowering, mean duration per plant (days); $N$, sample size; $\mathrm{CV}$, coefficient of variation (\%); SE, standard error. Masses are in grams of dry matter per plant.

Fig. 2. Percentage differences in aboveground biomass production, seed potential, reproductive ratio, seed ratio, and howering duration of wild pearl millet relative to cultivated pearl millet. See Table 1 for subheadings.

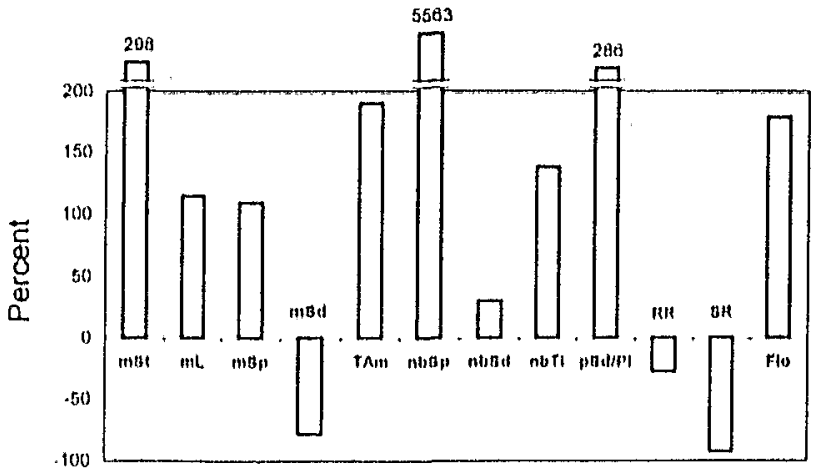

period took place between this date and the harvest. At harvest (90 DAE), $58 \%$ of the wild plants were still producing flowers. The flowering period of the cultivated pearl millet thus took place entirely within that of the wild pearl millet.

\section{Reproductive effort}

Except for the number of seeds per plant, all the results related to reproductive effort were significantly different $(P<0.05)$ between the two forms of pearl millet (Table 1 ; Fig. 2). Compared with a cultivated plant, a wild plant had the following characteristics: $(i)$ the number of spikes was 57 times greater, but it represented a total mass only twice as much as the spikes of a cultivated plant because of the larger size of the spikes of cultivated plants; (ii) the number of seeds per plant was not significantly different from that of cultivated pearl millet (4158 as opposed to 3194) but corresponded to a mass 4.5 times less $(4.9 \mathrm{~g}$ as opposed to $22.6 \mathrm{~g}$ for the cultivated pearl millet) because of the larger size of the seeds of the cultivated plants; (iii) the investment in the number of seeds produced compared with the total biomass was half (10 seeds/g of dry matter as opposed to $22 \mathrm{sec}$ s/g of dry matter for a cultivated plant), this being duc principally to the difference in the average number of seeds per spike (46 for a wild plant, 1996 for a cultivated plant).

The average reproductive ratios (RR) of wild and cultivated plants were significantly different (18 and 25\%, respectively) but were still quite close compared with the seed ratio (SR), which was 14 times less for a wild plant than for a cultivated plant (I and $14 \%$, respectively). A wild plant had on average 16.2 primary tillers, each producing on average 5.6 spikes. A cultivated plant had on average 6.8 primatry tillers and produced 0.3 spikes for each of them. Therefore, a large proportion of its tillers did not produce any spikcs.

The cultivated pearl millet attained $40 \%$ of its estimated potential in terms of seed production (real number of secds per plant (nbSd) divided by the potential number ( $\mathrm{pSd} / \mathrm{pl})$ ). Although the wild pearl millet produeed a quantity of secds equivalent to that of cultivated pearl millet, it had attained only $13 \%$ of its potential, which was 3.8 times higher than that of the cultivated pearl millet.

\section{Discussion}

This study shows that under experimental conditions, the cultivated pearl millet was always influenced by the wild pearl millet pollenic cloud, whereas the wild pearl millet population escaped from the cultivated pollenic cloud for a large part of its flowering period. If there had not been a harvest, the length of the endogamous reproduction of the sample of wild plants would have depended on the availability of water in the soil. According to Marchais (1994), under natural conditions in Niger, the observation of the flowering of a sample of tillers in a population of wild pearl millet revealed that $40 \%$ of the spikes were still flowering when the plants of the cultivated and shibra phenotypes had finished. The latter observation does not provide any information on the fraction of individual plants that participate in the endogamous system but supports the idea of strong endogamy in a wild pearl millet population.

For cultivated as for wild pearl millet, the average flowering period of a single plant was much shorter than the total 
flowering period of the whole population sample, particularly for the cultivated plants. One of the main effects of domestication is to synchronize the flowering of plants (Harlan et al. 1973). In the case of pearl millet, the larger variation (higher $\mathrm{CV}$ ) of the flowering periods of cultivated plants compared with wild plants indicates that domestication has not selected strongly for uniform ripening. Another consequence of domestication is to prevent the shedding of seeds and provide for simultaneous harvesting. This character has been selected for in cultivated pearl millet. However, because the farmer could need early-ripened grain for food and also to avoid predation by birds or insects, the same field can be harvested up to three times in the same crop season. Under Sahelian conditions, the advantage for farmers having a crop with a large interindividual variability in the flowering period could be to escape the risks of short-term stresses (water or pests) during the flowering period.

The wild phenotype was characterized by the length of the tillering and flowering phases and also by an asynchronous flowering pattern among the plants. If the tendency to flower late has a genetic basis and an adaptive advantage, it might have been selected for during the course of evolution, maintaining a part of the wild populations isolated from the gene thow of the cultivated plants. However, in the farming environment, germination and growth patterns of the different populations of wild pearl millet and of the different fields of cultivated pearl millet are not simultaneous. Moreover, the shibra could play a bridging role in gene llow il their flowering periods overlap those of the two extreme forms. Then, under natural conditions, the global llowering periods of wild and cultivated populations of pearl millet should overlap more than under our experimental conditions.

If the inlegrity of the cultivaled phenotype can be explained hy anthropic selection, the integrity of the wild phenotype may resull from the combination of the tendency for endogamous reproduction and a range of predoncestication characters peculiar to it. like abundant tiller and spike formation. shedding of the secds, secd dormancy. ele. Under matural conditions these characters offer adaptive advantages compared with those from deviant forms, like shibra, which tend to resemble the cultivated form. In this study, the morphological characters compared are often interdependent. For cxample, for a wild population, the high and extended tillering results in a spread-out appearance of a large number of spikes and so amplifies the progeny engendered in endogamous situations. Moreover, this strategy favours the chances of reproductive suceess in an unpredictable environment.

In our experiment. the cultivated sample attained $40 \%$ of its potential in seed production with a secd ratio of $14 \%$, which corresponds to a yicld of $678 \mathrm{~kg} \cdot \mathrm{ha}^{-1}$. close to the upper limit in traditional farming conditions (Anand Kumar 1989). The wild sample attained only 1.3\% of its potential in seed production, with a seed ratio of $1 \%$. which corresponds to the lowest values mentioned for Sahelian monocotyledons (De Ridder et al. 1981). The seed production and seed ratio in the wild population are low partly because the latest spikes did not have the time to fully develop their seeds, and partly because there could be a difference between wild and cultivated plants in the sensitivity to external factors (temperature, humidity, factors of pollination, ctc.) causing failure in pollination or abortion.
Genetic introgression does not eliminate the phenotypic differences among wild, weedy, and cultivated relatives in a large range of environments in diverse taxa, like Oryza (Second 1982; Bezançon 1993), Zea (Docbley ot al. 1987; Docbley 1990), and Citrullus (Zamir et al. 1984). Differential selection gave rise to an agrosystem in which the ancestral and the derived form evolved. The undesirable deviants are counter-selected by the farmer, but in the case of pearl millet in the Sahel, these deviants have never been completely eliminated. It is interesting to consider that the continual introgression of wild genes in the cultivated forms could permit a "genetic adjustment" of the crop to the widely variable habitat conditions typical of the Sahel.

\section{Acknowledgements}

We gratefully acknowledge Dr. G. Bezançon, Institut Français de Recherche Scientifique pour le Développement en Coopération (ORSTOM), Dr. K. Anand Kumar, International Crops Research Institute for the Semi-Arid Tropics (ICRISAT), G.H. Sehmelzer, Centre Régional de Formation et d'Application en Agrométéorologie et Hydrologie Opérationnelle (AGRHYMET), A. Stanciof' (AGRHYMET), and two reviewers for their useful comments and critiques, Dr. W. Payne (ICRISAT) for the collection of wild and cultivated seeds, and D. Taylor for the translation of a former version of the manuscript. This study was possible by assistance from ICRISAT for linancing the collection lour, from the Institut des Radio-Isotopes (IRI, University of Niamey) for experimental field and technical assistance, and ORSTOM for financing the research.

\section{References}

Amblatd, S., and Pernes, s. 1989, The iclentification of cultivated

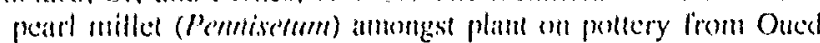
Chobhi (Dhat Oualatas. Maturitania). Alt. Archool. Rev. 7: $117-126$.

Amoukou. A.1.. and Marchais, L. 1993. Lvidence of a partial reproductive barrier between wild and cultivated pearl millets (Pconisctum glaucum). Euphytica, 67: 19-26.

Anand Kumar, K, 1989. Pearl millet: current slitus and future potential. Outlook Agric. 18: 46-53.

Bezançon, G. 1993. Le riz cultivé d'origine africaine Oryza glaberrima Steud. el les formes sauvages et adventices apparentes: diversite, relations génétiques et domestication. Thèse de Doctorat d'État. Université Paris XI. Orsay, France.

Burton, G.W., and Powell. J.B. 1968. Pearl millet breeding and cytogenetics. Adv. Agron. 20:49-89.

Clément, J.C. 1985. Les mils pénicillaires de l'Alrique de l'Ouest. Prospections et collectes IBPGR-ORSTOM. International Board for Plant Genetic Resoures. Food and Agriculture Organization, Rome, Italy.

De Ridder, N., Seligman, N.G., and van Keulen, H. 1981. Analysis of environmental and species effects on the magnitude of biomass investment in the reproductive effort of annual pasture plants. Oecologia, 49: 263-271.

Doebley, J. 1990. Molecular evidence for gene llow among Zea species. Bioscience, 40: 443-448.

Doebley, J.F., Goodman, M.M., and Stuber, C.W. 1987. Palterns of isozyme variation between maize and Mexican annual teosinte. Econ. Bot. $41: 234-246$.

Harlan, J.R. 1975. Crops and man. Americin Society of Agronomy, Crop Science Sixiety of Amcrica. Madison, itis. 
Harlan, J.R., and de Wet, J.M.J. 1971. Toward a rational classification of cultivated plants. Taxon, 20: 509-517.

Harlan, J.R., de Wet, J.M.J., and Price, E.G. 1973. Comparative cvolution of cereals. Evolution, 27: $311-325$.

Institut National de Recherches Agronomiques du Niger. 1987. Catalogue des varićtćs recommandécs de mil, sorgho, niébé et autres cultures du Niger. Ministère du Développement Rural, Niamey, Niger.

Joly-Ichenhauser, H. 1984. Hérédité du syndrome de domestication chez le mil Pennisetum typholdes : étude comparée de descendances $\left(F_{2}\right.$ et $R C$ ) issues de croisements entre plusieurs géniteurs cultivés et spontanés. Thèse de 3 me cycle, Université Paris XI, Orsay, France.

Marchais, L. 1994. Wild pearl millet population (Pennisetum glaucum, Poaceae) integrity in agricultural Sahelian areas. An example from Keita (Niger). Plant Syst. Evol. 189: 233-245.

Marchais, L., and Tostain, S. 1992. Bimodal phenotypic structure of two wild pearl millet samples collected in agricultural area. Biodiversity Conserv. 1: 170-178.

Pernès, J. 1983. Points de vue génétiques sur la domestication des céréales. Recherche (Paris), 146: 910-919.

Pernès, J. 1985. Evolution des plantes cultivées : l'exemple des céréales. Vie Sci, 2: 429-447.

Pernès, J. 1986. L'allogamie et la domestication des céréales : l'exemple du maïs (Zea mays L.) et du mil (Pennisenum americamum L. K. Schum.). Bull. Soc. Bot. Fr. 133: 27-34.

Portères, R. 1976. African cereals: eleusine, fonio, black fonio, teff, bracchiaria, paspalum, pennisetum and african rice. In
Origins of African plant domestication. Edifed by J.R. Harlan, J.M.J. de Wet, and A.B.M. Stemler. Mouton Publishers, The Haguc, The Netherlands. pp, 409-452.

Rey-Herme, C. 1982. Les relations génétiques entre formes spontanées et cultivées chez le mil (Pennisetum sp.). Thèse de 3 me cycle, Université Paris XI, Orsay, France.

Robert, T., Lespinasse, R., Pernès, J., and Sarr, A. 1991. Gametophytic competition as influencing gene flow between wild and cultivated forms of pearl nillet (Pennisenm typhoides). Genome, 34: 195-200.

Sarr, A., Sandmeier, M., and Pernès, J. 1988. Gametophytic competition in pearl millet Pennisetum ryphoiddes (Stapf and Hubb). Genome, 30: 924-929.

Second, G. 1982. Origin of the genetic diversity of cultivated rice (Oryza spp.): study of the polymorphism scored at 40 isozyme loci. Jpn. J. Genet. 57: 25-57.

Skerman, P.J., and Riveros, F. 1990: Propical grasses. Food and Agriculture Organization, Rome, Italy.

Tostain, S. 1993. Evaluation de la diversité des mils penicillaires diploïdes (Pennisetum glaucum (L. R.Br.)) au moyen de marqueurs enzymatiques. Etudes des relations entre formes sauvages et cultivées. Thèse de Doctorat, Université Paris XI, Orsay, France.

Van der Zon, A.P.M. 1992. Graminées du Cameroun. Vol. 2. Flore. Wageningen Agric, Univ, Pap. No, 92-1.

Zamir, D., Navot, N., and Rudich, J, 1984. Enzyme polymorphism in Citrullus lanatus and $C$. colocymthis in Israel and Sinai. Plant Syst. Evol, 146: $163-170$. 